\section{Commercial rocketry}

\section{One for Ariane}

Ariane, the European satellite launcher, has at last won a commercial place in the United States market. Last week, Arianespace, the French-based company which manages commercial exploitation of the European rocket, signed a firm $\$ 50$ million contract with the US General Telephone \& Electronics (GTE) Satellite Corporation to launch two telecommunications satellites in 1984. The order, the first that Arianespace has won from an American customer, seems to confirm at least some of the fears of US space officials that Ariane could take business from the National Aeronautics and Space Administration, which until now has enjoyed a virtual monopoly outside the Eastern bloc for launching heavy satellites.

Ariane's chief attraction for US customers, who enjoy a 25 per cent discount, is its relatively low cost. At about $\$ 25-\$ 30$ million per satellite, an Ariane launch is $15-20$ per cent less than a launch on a Thor-Delta rocket. Delays and uncertainties over the space shuttle have also made Ariane more competitive. Arianespace is optimistic that last week's deal will be followed by others.

Arianespace officials seem pleased with their own marketing efforts and those of the Grumman Corporation, their US agents. Twenty-one satellites from twelve customers, mainly European, have so far been committed for launch on sixteen Ariane flights. Three firm contracts, including that with the GTE Satellite Corporation, have been signed and sealed since the third successful Ariane test flight last July. In addition, ten potential customers hold reservations for launching sixteen satellites on nine Ariane flights.

The order books are as healthy as can be expected after only three out of four test flights, according to Arianespace. Their future health, however, will depend on the fortunes of the fourth test flight scheduled for 18 December.

Judy Redfearn

\section{European cooperation

COST in limbo

\section{Brussels}

The celebrations last week marking the tenth anniversary of COST, an organization pursuing "European Cooperation in the Field of Scientific and Technical Research", were appropriately low-key. Indeed, the role of COST itself has become so unobtrusive that its officials fear that its future is endangered by widespread ignorance of its purpose and even of its existence.

The chairman of the COST Senior Officials Committee, Johan Martin-Löf, speaking to the small group of senior officials and diplomats which had gathered to celebrate the anniversary, did his best to emphasize COST's solid achievements: that 35 different research projects had begun in the past decade, ten of them had been completed, and that this had involved ten EEC member states and nine other West European countries, all for a small extra outlay.

Part of COST's problem is that it is not a conventional international organization but a club which invites member countries to share the results of usually public

\title{
Harsh sentence for Paritskii
}

A Khar'kov court has sentenced Aleksandr Paritskii, a 43-year-old specialist in electronics, to three years in a labour camp. The sentence was the maximum possible for his formal offence - disseminating anti-Soviet propaganda. Its severity may be due to one of Paritskii's activities which was not mentioned in the formal charge the organization of a weekend "university" for young refusniks and the children of Jewish activists.

Exclusion from higher education is one of the regular sanctions imposed on those Jews caught in the limbo between applying for an emigration visa and actually being allowed to leave the country, and a fortiori on those formally refused permission to leave. Although since 1973 an increasing number of unofficial seminars have been organized for refusniks excluded from employment in the academic professions, until recently nothing formal had been done at undergraduate level.

In autumn 1980, however, Paritskii and a handful of fellow activists in

Khar'kov founded their 'refusniks' university" 'with 25 students. Structured courses were held every weekend, throughout the academic year. Mounting harassment of Paritskii, followed by his arrest, has made it impossible for the university to reconvene this year.

The absence of the university from Paritskii's charge-sheet is interesting. Paritskii's colleagues from the "university" were not even called in for interrogation in connection with his trial. This may well mean that the authorities fear that an open attack on the "university" may simply result in a similar initiative springing up elsewhere and hope that with Paritskii gone, the "university" will simply disappear. Certainly the authorities seem to be interested in undermining his academic reputation. Earlier this year, he was one of three refusnik scientists who, in a move unprecedented in the Soviet Union, were deprived of their "Candidate" (PhD) degrees because of their political views. research. Once a project has been agreed by the intricate committee structure, individual member countries select the aspects they wish to work on and by financing only its own share of a project, each participant country has the right to the results of the entire research effort.

COST's vague status has complicated the administrative problems of coordinating the research programmes of 19 countries. A small secretariat in Brussels is its only direct physical manifestation. A major obstacle for those taking part in COST projects is the financing of travel. And Martin-Löf admits that "the time it takes to handle even relatively simple matters is often excessive". A further problem is the lack of money for the administration of projects once launched.

Suggestions for new projects have to come from the member states themselves and the most dynamic field for new projects seems to be in telecommunications, transport and materials science. Last week, a memorandum of understanding was signed for the COST project on hightemperature materials for power plants.

Jasper Becker

\section{Asian ecology}

\section{Loss of balance}

\section{Bangalore}

The increasing demand for wood for fuel in Nepal and Thailand is threatening the ecological balance of a large part of South Asia. In Nepal, deforestation is so rapid that it has been estimated that the country will be without forest by the year 2000 .

The lack of tree cover is already causing two major problems. First, the once fertile valley lands are losing their ability to assimilate rainwater, causing a decline in vegetation, fast-spreading aridity and bird migration. Second, an estimated 240 million cubic metres of top soil is being carried into streams and rivers flowing into India and Bangladesh.

It was not until 1976 that the Nepalese government acknowledged the magnitude of the danger. It has now launched a 400 million rupee project, to be financed by the International Development Agency and other organizations, which aims to convert nearly 50,000 hectares of land into community forests over the next five years to meet the growing need for firewood.

In Thailand the government is also undertaking a replanting scheme concentrating on high-yielding rubber trees. The old unproductive rubber trees are to be used as construction materials in a plan which should, says the Thai Agriculture Ministry, bring in around $\$ 60$ million. Trials have shown that trees can be sprayed with chemicals and conserved at plantation sites for up to two years - at present more than 80 per cent of old rubber trees are felled and burned in a haphazard manner. Agricultural scientists have also examined the possibility of using the old trees for pulp.

B. Radhakrishna Rao 